\title{
Exploring the Relationship between Interest in Higher Education and 12th Grade Mathematics NAEP Scores
}

\author{
Caitlyn Kolhoff $^{1}$, and Mingyuan Zhang ${ }^{2 *}$ \\ ${ }^{1,2}$ Central Michigan University, United States of America \\ *e-mail: zhang1m@cmich.edu
}

\begin{abstract}
This study presented a secondary analysis of the National Assessment of Educational Progress (NAEP) dataset. The paper examined if a gap exists between the mathematics scores of 12th-grade public school students who have different levels of interest in higher education. - This study used a quantitative descriptive research design to analyze data from the 2013, 2015, and 2019 NAEP data sets. The findings include (1) the average mathematics scale score of students who complete college entrance exams, ACT/SAT, is higher than those who do not complete these exams. (2) The average mathematics scale score of students who complete the FAFSA is higher than those who do not complete the FAFSA. (3) Students who applied to four-year colleges performed significantly higher on the 12th-grade mathematics NAEP than those who did not. (4) Students who applied to twoyear colleges performed significantly lower on the 12th-grade mathematics NAEP than those who did not. (5) Students who perceived a future benefit to mathematics scored higher on the mathematics NAEP. These findings indicate that students who are interested in higher education, particularly four-year education, do have higher 12th NAEP mathematics scores. These findings may provide insight into college preparation and guidance at the high school level.
\end{abstract}

Keywords:

NAEP, Mathematics Proficiency, Higher Education, FAFSA, Readiness.

\begin{abstract}
ABSTRAK
Studi ini menyajikan analisis sekunder dari dataset National Assessment of Educational Progress (NAEP). Makalah ini meneliti apakah ada kesenjangan antara nilai matematika siswa sekolah umum kelas 12 yang memiliki tingkat minat yang berbeda dalam pendidikan tinggi. - Penelitian ini menggunakan desain penelitian deskriptif kuantitatif untuk menganalisis data dari kumpulan data NAEP 2013, 2015, dan 2019. Temuan tersebut
\end{abstract}


antara lain (1) nilai rata-rata skala matematika siswa yang menyelesaikan ujian masuk perguruan tinggi, ACT/SAT, lebih tinggi daripada mereka yang tidak menyelesaikan ujian tersebut. (2) Rata-rata skor skala matematika siswa yang menyelesaikan FAFSA lebih tinggi daripada mereka yang tidak menyelesaikan FAFSA. (3) Siswa yang mendaftar ke perguruan tinggi empat tahun berprestasi secara signifikan lebih tinggi pada NAEP matematika kelas 12 dibandingkan mereka yang tidak. (4) Siswa yang mendaftar ke perguruan tinggi dua tahun berprestasi secara signifikan lebih rendah pada NAEP matematika kelas 12 dibandingkan mereka yang tidak. (5) Siswa yang merasakan manfaat masa depan untuk matematika mendapat nilai lebih tinggi pada NAEP matematika. Temuan ini menunjukkan bahwa siswa yang tertarik pada pendidikan tinggi, khususnya pendidikan empat tahun, memiliki nilai matematika NAEP 12 yang lebih tinggi. Temuan ini dapat memberikan wawasan tentang persiapan dan bimbingan kuliah di tingkat sekolah menengah.

\section{Kata Kunci:}

NAEP, Pendidikan Tinggi, FAFSA, Kesiapan.

\section{Introduction}

In 2018, 69.1\% t of high school graduating seniors enrolled in tertiary education (Bureau of Labor Statistics, 2020). However, only 60.9\% completed the Free Application for Federal Student Aid (FAFSA) by the application deadline (Smith-Barrow, 2018). This difference may imply that there are gaps in financial literacy between graduating seniors. Moreover, this gap in financial literacy might also be reflected in standard test outcomes. Additionally, college entrance exams, such as the SAT and ACT, were strong indicators of '"students' likelihood to seek out postsecondary programs. Differences in interest toward, and preparation for, college could be related to a '"'"'Student's score on the 12th-grade NAEP mathematics test as well. The purpose of this project is to explore if a gap exists between the mathematics scores of 12th-grade public school students who have different levels of interest in higher education.

Previous research illustrates that students who performed well on college entrance exams will also perform well on their 12th grade NAEP (Scott, Ingles, \& Owings, 2007). This relationship has been examined to be steady over time (Schneider, Kitmitto, Muhisani, \& Zhu, 2015). These tests provide a pathway to higher education. Improved pathways and a shift in the prioritization of higher education have led to steady enrollment over the last decade. While the immediate enrollment from high school to higher education has remained steady over the last decade, college retention has not. Higher education costs are rising for students as funding models have decreased state funding, resulting in more reliance on tuition. This has resulted in increased financial barriers for students. Financial aid is designed to be a tool to help students persist in higher education by reducing these financial barriers (Alon, 2011). 
Research on the FAFSA has illustrated one of the best indicators of high school students enrolling in college immediately upon graduation (National Collegiate Attainment Network, 2021). Additionally, students who file a FAFSA are more likely to persist in higher education (Novak \& McKinney, 2011; McKinney \& Novak, 2012, 2015). Filing a FAFSA before entering college is an early indicator of financial literacy. It shows that students are aware of the steps they need to apply for federal financial aid. Financial literacy can play an essential role in a student's higher education experience. Students with financial literacy skills, or those with a support system that helps foster these skills, can better manage their expenses, find funding sources for college, and even improve persistence rates (Kafka, 2019).

In recent years, there has been a push to improve FAFSA completion for secondary school graduates by developing tailored interventions towards previously underrepresented groups (Owen $\& W e s t l u n d, 2016)$. Students are more likely to have completed the FAFSA if motivated to pursue higher education (McKinney \& Novak, 2015). Just as standardized test scores and access to financial resources can indicate student success, interest factors also play a role in student outcomes. Previous research on the NAEP has shown that students with a higher interest in mathematics will score higher on the NAEP (Bohrnstedt, Zhang, Pakr, Ikoma, Broer, \& Ogut, 2020). This illustrates the importance of nurturing a "' Student's interest in mathematics, as it can impact academic outcomes and be a marker of their likelihood to transition to postsecondary education.

Although postsecondary planning has been seen as a marker of success on the NAEP, few studies have examined its intersection with motivation. Moreover, the mathematics subject matter of NAEP may be beneficial because of its connection to financial literacy skills. Financial literacy and mathematics education may be connected as finance is rooted in mathematics (Carpena, Cole, Shapiro, \& Zia, 2011). Examining NAEP performance about mathematical interest and steps toward postsecondary education may further illuminate this interaction.

Utilizing NAEP data relating to high school seniors provides essential evidence for high school administrators, guidance counselors, and college admissions departments. This research will show if recent actions to encourage financial literacy and test preparation are also improving academic outcomes for high school administrators. The findings will provide university admissions departments with the information they can use to understand better how high school students are preparing for higher education. Moreover, these universities may be interested in increasing FAFSA completion as well, as students who complete the FAFSA are more likely to remain in tertiary education programs

To better understand if a gap exists between the mathematics scores of 12th-grade students who have different levels of interest in tertiary education, this study will explore the following research questions:

Q1: How does taking college entrance exams relate to 12th-grade NAEP mathematics scores? 
Q2: How does complete the FAFSA relate to 12th-grade NAEP mathematics scores?

Q3: How does apply to college relate to 12th-grade NAEP mathematics scores?

Q4: Does a 'Student's perceived benefit of mathematics impact their 12th-grade NAEP mathematics scores?

These research questions were developed after reviewing the 12th-grade mathematics NAEP dataset and exploring existing literature dealing with the transition to tertiary education and academic achievement. Several factors influence whether a student will progress from high school to college. The two that have received focused attention in previous research are socio-economic status (Avery \& Kane, 2004) and support networks (Bettinger \& Evans, 2019). First, students from low incomes have been less likely to go to college (Avery \& Kane, 2004). Individuals from this socio-economic group, even $35 \%$ of those with a 3.0 or higher, do not attend 2- or 4-year tertiary education programs (Avery \& Kane, 2004). This can be because the system for applying to college and finding financial support for tertiary education can be complicated without help from their high school or family support systems (Bruce \& Bridgeland, 2014).

While studies have illustrated that high-income students with parents involved in their education often move on to higher education (Erickson, McDonald, \& Elder, 2009), high schools can foster interest in college by implementing interventions designed to help students enrol and persist in higher education. These programs focus on academic outcomes and counselling for college and financial planning (Schneider, Broda, Judy \& Burkander, 2013). Often, these programs rely on bringing in mentors who are currently enrolled in college to work with students (Bettinger \& Evans, 2019).

When students and parents receive guidance on how to complete their FAFSA, completion rates are improved. Bettinger et al. (2012) found that giving parents streamlined personal assistance when completing the FAFSA resulted in their students being more likely to apply for financial aid, attend college, and receive aid. High school guidance counsellors are positioned to provide adequate college counselling and to assist with navigating financial aid. The U.S. Department of Education initiated the FAFSA completion project to provide real-time completion data to school districts across the county. This data was then used by high school guidance counselors to provide direct support to their students (Owen \& Westlund, 2016). The FAFSA has also been shown to have a relationship with a 'Student's academic performance. Students with strong academic performance are more likely to complete the FAFSA (Feeny \& Heroff, 2013). This research found that students who were already successful academically would take the additional steps to prepare for college. Once enrolled in college, filing a FAFSA has been linked to improved persistence. McKinney and Novak (2012) found that community college students who filed a FAFSA had higher persistence rates between their freshman and sophomore years. This further illustrates how filing a FAFSA can reduce the financial barriers that impede access to higher education.

Motivational factors can shift for students during high school based on their experiences, social support, and personal identity with mathematics. Mangu et al. (2015) explored motivational 
factors that influenced high school students to pursue STEM-related fields. Their study found that students between 9th and 11th grade would change their occupational intentions as they encountered difficulties with STEM early in their high school career. Further, motivation for students is goal-oriented. Goal proximity, specificity, and focus can all impact the "'Student's motivation and experience with mathematics. "'learners must see how their mathematics content can contribute to their interests and identity over time (Hannula et al., 2016). Students enrol in higher education when supported by resources. These can come in multiple forms, mentorship about college, information about how to apply for funding, and opportunities to explore their interests. Studies illustrate that factors relating to college prep led to improved academic performance and persistence in higher education. This study will examine if these factors are connected to student performance on the 12th-grade mathematics NAEP.

Our theoretical framework for this research adopts a scientific inquiry-based approach. The framework was described in great detail in The Impact of Conversations on Fourth Grade Reading Performance - What NAEP Data Explorer Tells? (Bond \& Zhang, 2017). The research methods combined the inquiry process with scientific knowledge, reasoning, and critical thinking. We started with an extensive exploration of the dataset, which led to designing the research questions. The research questions further guided us to mine the data with great in-depth.

\section{Methods}

This study used quantitative methods to evaluate the interaction between factors relating to interest in and preparation for higher education and NAEP mathematics scores. The following section will first explain what the NAEP is before justifying analyzing the NAEP mathematics. Then discuss how the data was analyzed.

\subsection{What is the NAEP}

The National Assessment of Educational Progress (NAEP) is the largest nationally representative and continuing assessment of what students in public and private schools in the United States know and can do in various subjects" "“" (NCES, 2018a). This test is given every two years to a representative sample of students from grades 4, 8, and 12 across the United States. NAEP has developed into one of the preferred mechanisms for understanding the academic development of U.S. students over time (Zhang \& Li, 2009). Referred to as ""'""the ' 'Nation's Report Card""'"", NAEP results are reported at a federal and state level (LaDell-Thoman \& Zhang, 2017). Similar questions are used year-to-year and across the nation to ensure the results can be compared across multiple geographic areas, districts, educational settings, and even years. Moreover, the test results can be further subdivided thanks to the inclusion of extensive demographic questionnaires. 


\subsection{NAEP Background Questionnaires}

The NAEP asks a plethora of demographic questions ranging from gender, race, and ethnicity to Title I status and school size. Background questionnaires are included in the NAEP to help contextualize the results. There are three types of survey questionnaires: Student, teacher, and school. The student questionnaire provides information on 'students' educational experiences, demographics, and opportunities to learn. The teacher questionnaire focuses on teacher training and instructional practices. Lastly, the school questionnaire is intended to gather information on school policies and characteristics from administrators (NCES, 2018b). While these background questionnaires are similar across different subject matter tests, these assessments also have their scales to contextualize results specific to that subject area better.

\subsection{NAEP Mathematics Questionnaire}

The NAEP Mathematics Questionnaire is administered to 4th and 8th graders every two years and to 12th graders every four years. This assessment measures 'students' ability to problems solving using mathematical knowledge and their general skill in mathematics (NCES, 2020a). Similar to the other subject-matter tests, the mathematics background questionnaires are designed to explore better students' home factors, motivation, and general experience and interest in the subject. Specifically, within the 12th-grade questionnaire, students are asked to identify steps they have taken to transition to postsecondary education.

\subsection{Participant Data and Sampling}

The data in this study was drawn from the 2013, 2015, and 2019 NAEP, 12th-grade student mathematics assessments of public-school students. This period was chosen for two reasons. First, evaluating NAEP mathematics scores, interest in higher education, and motivation may fluctuate over time in response to educational interventions. Second, this data was also the most recent and representative data points of the current educational environment. Because this data is drawn from the NAEP, each of these subject matter tests are representative samples, which utilize a multistage probability design (NCES, 2020b). The 12th-grade mathematics assessment is sampled every four years from select public and private schools across the United States. This study examined public school data. Within these schools, 12th graders are randomly selected to participate in the assessment. The number of participants varies from year to year with the NAEP; however, the sample typically consists of 10,000-20,000 students per subject (NCES, 2020c).

\subsection{Data Analysis}

Empirically, research on the NAEP is conducted through the NAEP Data Explorer. This webbased tool provides researchers with access to presentation models of NAEP results (NCES, 2008). This study used the NAEP Data Explorer to analyze NAEP 12th-grade NAEP mathematics scores and background questionnaire items. Mathematics composite scores, questions from the student 
interest in mathematics scale, and categorical factors of college interest were examined. The following six questionnaires were chosen from the NAEP student mathematics questionnaire:

(1) Taken the SAT or ACT College Entrance Exams [VH740702]

(2) Submitted the Free Application for Federal Student Aid [VH740703]

(3) Applied to a 2-year college [VH740704]

(4) Applied to a 4-year college [VH740706]

(5) I take mathematics because it will help me in the future [VH731859]

(6) I take mathematics to meet my high school graduation requirements [VH731856]

The result of the NAEP mathematics composite score was compared to the answers students provided to these questions. The Data Explorer was used to create descriptive tables and tests of statistically significant differences. ' 'Cohen's $d$ effect sizes were calculated using an online effect size calculator (Becker, 2000). ' 'Cohen's $d$ is the difference between the means of two independent groups, divided by the standard deviation of either group (Cohen, 1988). This statistic is used to evaluate the degree of difference between the means of two groups, with 0.0-0.2 indicating a small degree of difference and values above 0.8 indicating a large effect size and high percent nonoverlap.

\section{Results and Discussion}

This section will report the results of examining interest in higher education factors and the perceived benefit of mathematics against the NAEP 12th-grade mathematics composite scores for twelfth-grade students in 2013, 2015, and 2019. Variables include completion of college entrance examinations, completing the FAFSA, applying to two- and four-year colleges, and the S' 'Student's perceived benefit of mathematics. The results include the means and standard deviations for each variable examined.

3.1. Research Question 1: How does taking college entrance exams relate to 12th-grade NAEP mathematics scores?

To answer research question one, the question "Student has taken the SAT/ACT" was compared to the average NAEP composite scale score. The following table displays the results for national public-school students in the years 2019, 2015, and 2013.

The data gathered through the NAEP Data Explorer indicates students who had taken college entrances exams scored significantly higher on the NAEP, $p>.001$. This trend is consistent across the sampled years. ' 'Cohen's $d$ effect sizes were calculated using an online effect size calculator (Becker, 2000). ' 'Cohen's $d$ is the difference between the means of two independent groups, divided 
by the standard deviation of either group (Cohen, 1988). A Cohen's $d$ was calculated for each of the sampled years $(2019, d=.14 ; 2015, d=.41 ; 2013, d=.42)$. In 2019 the effect was smaller than in prior years.

Table 1. Average scale scores and standard deviations for grade 12 mathematics, by took SAT or ACT: 2019, 2015, and 2013

\begin{tabular}{llccc}
\hline Year & Jurisdiction & $\begin{array}{c}\text { The student has taken } \\
\text { the SAT/ACT }\end{array}$ & $\begin{array}{c}\text { Average } \\
\text { Scale Score }\end{array}$ & $\begin{array}{c}\text { Standard } \\
\text { Deviation }\end{array}$ \\
\hline 2019 & National Public & Yes & $152^{* *}$ & 35 \\
\hline 2019 & National Public & No & 147 & 36 \\
\hline 2015 & National Public & Yes & $156^{* *}$ & 33 \\
\hline 2015 & National Public & No & 142 & 34 \\
\hline 2013 & National Public & Yes & $158^{* *}$ & 32 \\
\hline 2013 & National Public & No & 144 & 34 \\
\hline
\end{tabular}

**Students scored significantly higher on NAEP mathematics, $p=>0.001$

3.2. Research Question 2: How does complete the FAFSA relate to 12th-grade NAEP mathematics scores?

Table 2. Average scale scores and standard deviations for grade 12 mathematics, by submitted FAFSA: 2019, 2015, and 2013

\begin{tabular}{llccc}
\hline Year & Jurisdiction & $\begin{array}{c}\text { The student has } \\
\text { submitted } \\
\text { FAFSA }\end{array}$ & $\begin{array}{c}\text { Average Scale } \\
\text { Score }\end{array}$ & $\begin{array}{c}\text { Standard } \\
\text { Deviation }\end{array}$ \\
\hline 2019 & National Public & Yes & $157^{* *}$ & 35 \\
\hline 2019 & National Public & No & 139 & 34 \\
\hline 2015 & National Public & Yes & $158^{* *}$ & 34 \\
\hline 2015 & National Public & No & 144 & 33 \\
\hline 2013 & National Public & Yes & $161^{* *}$ & 32 \\
\hline 2013 & National Public & No & 145 & 33
\end{tabular}

**Students scored significantly higher on NAEP mathematics, $p=>0.001$

To answer research question two, the question "Student has submitted FAFSA" was compared to the average NAEP composite scale score. The following table 2 displays the results for national public-school students in the years 2019, 2015, and 2013. 
The data gathered through the NAEP Data Explorer indicates that students who had submitted a FAFSA scored significantly higher on the NAEP, $p>.001$. This trend is consistent across the sampled years. A Cohen's $d$ was calculated for each of the sampled years $(2019, d=.52 ; 2015, d$ $=.42 ; 2013, d=.49)$. There was a moderate effect in general, with the effect being slightly larger in 2019 (Cohen, 1988).

\subsection{Research Question 3: How does applying to college relate to 12th-grade NAEP mathematics scores?}

To answer research question three, the questions "student has applied to two-year college" and "student has applied to four-year college" were compared to the average NAEP composite scale score. Tables 3 and 4 display the results for national public-school students in the years 2019, 2015, and 2013.

Table 3. Average scale scores and standard deviations for grade 12 mathematics, by applied to twoyear college: 2019, 2015, and 2013

\begin{tabular}{llccc}
\hline Year & Jurisdiction & $\begin{array}{c}\text { The student has } \\
\text { applied to a two- } \\
\text { year college }\end{array}$ & Average Scale Score & $\begin{array}{c}\text { Standard } \\
\text { Deviation }\end{array}$ \\
\hline 2019 & National Public & Yes & 139 & 31 \\
\hline 2019 & National Public & No & $156^{* *}$ & 37 \\
\hline 2015 & National Public & Yes & 140 & 29 \\
\hline 2015 & National Public & No & $154^{* * *}$ & 35 \\
\hline 2013 & National Public & Yes & 143 & 29 \\
\hline 2013 & National Public & No & $156^{* *}$ & 34 \\
\hline
\end{tabular}

**Students scored significantly higher on NAEP mathematics, $p=>0.001$

The results indicate that students who did not apply to two-year colleges scored significantly higher on the NAEP, $p>.001$. This trend is consistent across the sampled years. A Cohen's $d$ was calculated for each of the sampled years $(2019, d=.50 ; 2015, d=.44 ; 2013, d=.41)$. There was a moderate effect in general, with the effect being slightly larger in 2019 (Cohen, 1988).

The results indicate that students who applied to four-year colleges scored significantly higher on the NAEP, $p>.001$. This trend is consistent across the sampled years. A Cohen's $d$ was calculated for each of the sampled years $(2019, d=.90 ; 2015, d=.93 ; 2013, d=.96)$. The effect was large over all three sampled years (Cohen, 1988). 
Table 4. Average scale scores and standard deviations for grade 12 mathematics, by applied to a four-year college: 2019, 2015, and 2013

\begin{tabular}{llccc}
\hline Year & Jurisdiction & $\begin{array}{c}\text { The student has applied to a } \\
\text { four-year college }\end{array}$ & $\begin{array}{c}\text { Average Scale } \\
\text { Score }\end{array}$ & $\begin{array}{c}\text { Standard } \\
\text { Deviation }\end{array}$ \\
\hline 2019 & National Public & Yes & $162^{* *}$ & 34 \\
\hline 2019 & National Public & No & 133 & 30 \\
\hline 2015 & National Public & Yes & $164^{* *}$ & 32 \\
\hline 2015 & National Public & No & 135 & 30 \\
\hline 2013 & National Public & Yes & $166^{* *}$ & 31 \\
\hline 2013 & National Public & No & 137 & 29 \\
\hline
\end{tabular}

**Student scored significantly higher on NAEP mathematics, $p=>0.001$

3.4. Research Question 4: Does a student's perceived benefit of mathematics impact their 12thgrade NAEP mathematics scores?

To answer research question four, the questions "take math to meet my high school graduation requirements" and "I take mathematics because it will help me in the future" were compared to the average NAEP composite scale score. Tables 5 through 8 display the average scale scores and difference in scale scores for the response to "taking math to meet their high my high school graduation requirement". Tables 9 through 12 identify the average scale scores and difference in scale scores for the response to "taking because it will help me in the future".

Table 5. Average scale scores and standard deviations for grade 12 mathematics, by taking math to meet my high school graduation requirements: 2019

\begin{tabular}{ccccc}
\hline Year & Jurisdiction & $\begin{array}{c}\text { Take math to meet my high } \\
\text { school graduation requirements }\end{array}$ & $\begin{array}{c}\text { Average Scale } \\
\text { Score }\end{array}$ & $\begin{array}{c}\text { Standard } \\
\text { Deviation }\end{array}$ \\
\hline 2019 & National Public & Not at all like me & 145 & 44 \\
\hline 2019 & National Public & A little bit like me & 156 & 41 \\
\hline 2019 & National Public & Somewhat like me & 150 & 37 \\
\hline 2019 & National Public & Quite a bit like me & 155 & 34 \\
\hline 2019 & National Public & Exactly like me & 149 & 33 \\
\hline
\end{tabular}

Table 5 reports the average scale scores and standard deviations for 12-grade public-school students on the mathematics NAEP based on their response to "I take math to meet my high school 
graduation requirements" for 2019. The results indicate that students who felt this statement was "A little bit like me" scored the highest on the NAEP.

The ' 'Cohen's $d$ between the mean score of students who responded to "I take math to meet my high school graduation requirements", "Not at all like me", "somewhat like me", "quite a bit like me", or "exactly like me" and those reported "a little bit like me" were respectively $0.26,0.15,0.03$, and 0.19 . The highest effect was $d=0.26$ between students who reported "not at all like me" and "a little bit like me". This is a small effect (Cohen, 1988).

Table 6. Average scale scores and standard deviations for grade 12 mathematics, by taking math to meet my high school graduation requirements: 2015 and 2013

\begin{tabular}{ccccc}
\hline Year & Jurisdiction & $\begin{array}{c}\text { Take math to meet my high } \\
\text { school graduation requirements }\end{array}$ & $\begin{array}{c}\text { Average Scale } \\
\text { Score }\end{array}$ & $\begin{array}{c}\text { Standard } \\
\text { Deviation }\end{array}$ \\
\hline 2015 & National Public & Strongly Disagree & 153 & 43 \\
\hline 2015 & National Public & Disagree & 167 & 40 \\
\hline 2015 & National Public & Agree & 151 & 35 \\
\hline 2015 & National Public & Strongly Agree & 147 & 31 \\
\hline 2013 & National Public & Strongly Disagree & 156 & 43 \\
\hline 2013 & National Public & Disagree & 167 & 39 \\
\hline 2013 & National Public & Agree & 154 & 34 \\
\hline 2013 & National Public & Strongly Agree & 149 & 31 \\
\hline
\end{tabular}

Table 6 reports the average scale scores and standard deviations for 12-grade public-school students on the mathematics NAEP, based on their response to "I take math to meet my high school graduation requirements" for 2015 and 2013. The results indicate that students who answered "disagree" scored the highest on the NAEP.

For 2015, the Cohen's $d$ between the mean score of students who responded to "I take math to meet my high school graduation requirements" with strongly disagree, strongly agree, or strongly agree. Those who reported disagree, were respectively $0.34,0.43$, and 0.56 . The highest effect was $d=0.56$, between students who reported agree and strongly disagree; this is a moderate effect (Cohen, 1988).

For 2013, the Cohen's $d$ between the mean score of students who responded to "I take math to meet my high school graduation requirements" with strongly disagree, strongly agree, or strongly agree, and those reported disagree, were $0.27,0.36$, and 0.51 , respectively. The highest effect was 
$d=0.56$, between students who reported agree and strongly disagreed, this was also a moderate effect (Cohen, 1988).

Table 7. The difference in Average Scale Scores between Variables for Math for Graduation Requirements: 2019

\begin{tabular}{|c|c|c|c|c|}
\hline & 1 & 2 & 3 & 4 \\
\hline \multicolumn{5}{|l|}{ 1. Not at all like me } \\
\hline \multirow[t]{4}{*}{ 2. A little bit like me } & $>$ & & & \\
\hline & $\operatorname{Diff}=12$ & & & \\
\hline & $\mathrm{P}$-value $=0.0000$ & & & \\
\hline & Family size $=10$ & & & \\
\hline \multirow[t]{4}{*}{ 3. Somewhat like me } & $>$ & $<$ & & \\
\hline & Diff $=5$ & Diff $=-7$ & & \\
\hline & $\mathrm{P}$-value $=0.0084$ & P-value $=0.0006$ & & \\
\hline & Family size $=10$ & Family size $=10$ & & \\
\hline \multirow[t]{4}{*}{ 4. Quite a bit like me } & $>$ & $\mathrm{X}$ & $>$ & \\
\hline & Diff $=10$ & Diff $=-2$ & Diff $=5$ & \\
\hline & $\mathrm{P}$-value $=0.0000$ & P-value $=0.3992$ & P-value $=0.0002$ & \\
\hline & Family size $=10$ & Family size $=10$ & Family size $=10$ & \\
\hline \multirow[t]{4}{*}{ 5. Exactly like me } & $>$ & $<$ & $\mathrm{x}$ & $<$ \\
\hline & Diff $=4$ & Diff $=-8$ & Diff $=-1$ & Diff $=-6$ \\
\hline & $\mathrm{P}$-value $=0.0165$ & $\mathrm{P}$-value $=0.0000$ & $\mathrm{P}$-value $=0.4715$ & $\mathrm{P}$-value $=0.0000$ \\
\hline & Family size $=10$ & Family size $=10$ & Family size $=10$ & Family size $=10$ \\
\hline \multicolumn{5}{|l|}{ LEGEND: } \\
\hline$<$ & Significantly lower. & & & \\
\hline$>$ & Significantly higher. & & & \\
\hline $\mathrm{x}$ & No significant difference. & & & \\
\hline
\end{tabular}

Table 7 presents the difference in mean results for the response to "I take math to meet my high school graduation requirements", 2019. Alpha was set at 0.05. Overall, students who responded "not at all like me" scored significantly lower than those who chose any other category. Students who responded, "a little bit like me" scored significantly higher than those who responded, "somewhat like me" and "exactly like me", but did not have significant differences with those responding, "quite a bit like me". Students who responded, "quite a bit like me scored significantly higher than those who responded, "somewhat like me". Students responding "exactly like me" had no significant difference with students responding "somewhat like me" but did score significantly lower than those who responded "somewhat like me".

Table 8 presents the difference in means results for the response to "I take math to meet my high school graduation requirements", 2015. Alpha was set at 0.05. Students who responded, "strongly disagree" did not have any significant difference in scores with students who responded 
"agree" or "strongly agree"; however, they did have statistically lower scores than students who responded "disagree". Students who responded, "agree" scored lower than students who responded "disagree". Lastly, students who responded, "Strongly agree" scored lower than students who responded "agree" and those who responded "disagree".

Table 8. The difference in Average Scale Scores between Variables for Math for Graduation Requirements: 2015

\begin{tabular}{llll}
\hline & 1 & 2 & 3 \\
\hline 1. Strongly disagree & & & \\
2. Disagree & $>$ & & \\
& Diff $=14$ & & \\
& P-value $=0.0000$ & & \\
3. Agree & Family size $=6$ & & \\
& $\mathrm{X}$ & $<$ & \\
& Diff $=-1$ & Diff $=-15$ & \\
& P-value $=0.7267$ & P-value $=0.0000$ & \\
4. Strongly agree & Family size $=6$ & Family size $=6$ & \\
& $\mathrm{X}$ & $<$ & $<$ \\
& Diff $=-5$ & Diff $=-19$ & Diff $=-4$ \\
& P-value $=0.0625$ & P-value $=0.0000$ & P-value $=0.0000$ \\
LEGEND: & Family size $=6$ & Family size $=6$ & Family size $=6$ \\
$<$ & & & \\
$>$ & & & \\
$X$ & Significantly lower. & & \\
\hline
\end{tabular}

Table 9 presents differences in means results for the response to "I take math to meet my high school graduation requirements", 2013. Alpha was set at 0.05. Students who responded, "strongly disagree" had lower scores than those responding "disagree" and higher scores than those responding, "strongly agree"; however, they did not have any significant difference in scores with students who responded "agree". Students who responded, "agree" scored lower than students who responded "disagree". Lastly, students who responded, "Strongly agree" scored significantly lower than students in all other categories.

Table 10 reports the average scale scores and standard deviations for 12-grade public-school students on the mathematics NAEP, based on their response to "I take math because it will help me in the future" for 2019. The results indicate that students who felt this statement was "exactly like me" scored the highest on the NAEP.

The Cohen's $d$ between the mean score of students who responded to "I take math because it will help me in the future", "not at all like me", "a little bit like me", "somewhat like me", or "quite a bit like me" and those reported talk "exactly like me" were respectively 0.79, 0.43, 0.45, and 0.14. The highest effect was $d=0.79$ between students who reported "not at all like me" and "exactly like me", this is a moderate-to-large effect (Cohen, 1988). 
Table 9. Difference in Average Scale Scores Between Variables for Math for Graduation Requirements: 2013

\begin{tabular}{llll}
\hline & 1 & 2 & 3 \\
\hline $\begin{array}{ll}\text { 1. Strongly disagree } \\
\text { 2. Disagree }\end{array}$ & & & \\
& Diff $=11$ & & \\
& P-value $=0.0000$ & & \\
& Family size $=6$ & & \\
3. Agree & $\mathrm{X}$ & $<$ & \\
& Diff $=-2$ & Diff $=-14$ & \\
& P-value $=0.2775$ & P-value $=0.0000$ & \\
& Family size $=6$ & Family size $=6$ & \\
4. Strongly agree & $<$ & $<$ & Diff $=-5$ \\
& Diff $=-7$ & Diff $=-18$ & P-value $=0.0000$ \\
& P-value $=0.0019$ & P-value $=0.0000$ & \\
& Family size $=6$ & Family size $=6$ & Family size $=6$ \\
LEGEND: & & & \\
$<$ & Significantly lower. & & \\
$>$ & Significantly higher. & & \\
$X$ & No significant difference. & & \\
\hline
\end{tabular}

Table 10. Average scale scores and standard deviations for grade 12 mathematics, by taking math because it will help me in the future: 2019

\begin{tabular}{clccc}
\hline Year & Jurisdiction & $\begin{array}{c}\text { Take math because it will } \\
\text { help me in the future }\end{array}$ & $\begin{array}{c}\text { Average Scale } \\
\text { Score }\end{array}$ & $\begin{array}{c}\text { Standard } \\
\text { Deviation }\end{array}$ \\
\hline 2019 & National Public & Not at all like me & 135 & 31 \\
2019 & National Public & A little bit like me & 147 & 33 \\
2019 & National Public & Somewhat like me & 146 & 34 \\
2019 & National Public & Quite a bit like me & 157 & 34 \\
2019 & National Public & Exactly like me & 162 & 38 \\
\hline
\end{tabular}

Table 11 reports the average scale scores and standard deviations for 12-grade public publicschool students on the mathematics NAEP, based on their response to "I take math because it will help me in the future" for 2015 and 2013. The results indicate that students who answered "strongly agree" scored the highest on the NAEP.

For 2015, the Cohen's d between the mean score of students who responded to "I take math because it will help me in the future", "strongly disagree", "disagree", or "agree" and those reported talk "strongly agree" were respectively $0.81,0.51$, and 0.43 . The highest effect was $\mathrm{d}=0.81$ between 
students who reported "strongly agree" and "strongly disagree"; this is a significant effect (Cohen, 1988).

Table 11. Average scale scores and standard deviations for grade 12 mathematics, by taking math because it will help me in the future: 2015 and 2013

\begin{tabular}{ccccc}
\hline Year & Jurisdiction & $\begin{array}{c}\text { Take math because it will help } \\
\text { me in the future }\end{array}$ & $\begin{array}{c}\text { Average Scale } \\
\text { Score }\end{array}$ & $\begin{array}{c}\text { Standard } \\
\text { Deviation }\end{array}$ \\
\hline 2015 & National Public & Strongly Disagree & 136 & 30 \\
2015 & National Public & Disagree & 146 & 30 \\
2015 & National Public & Agree & 148 & 33 \\
2015 & National Public & Strongly Agree & 163 & 36 \\
2013 & National Public & Strongly Disagree & 139 & 30 \\
2013 & National Public & Disagree & 148 & 30 \\
2013 & National Public & Agree & 150 & 32 \\
2013 & National Public & Strongly Agree & 164 & 35 \\
\hline
\end{tabular}

For 2013, the Cohen's d between the mean score of students who responded to "I take math because it will help me in the future", "strongly disagree", "disagree" or "agree" and those reported talk "strongly agree" were respectively $0.77,0.49$, and 0.42 . The highest effect was $\mathrm{d}=0.77$ between students who reported "agree" and "strongly disagree"; this is a moderate-to-large effect (Cohen, 1988).

Table 12 presents the difference in means results for the response to "I take math because it will help me in the future", 2019. Alpha was set at 0.05. Overall, students who responded "not at all like me" scored significantly lower than those who chose any other category. There was no significant difference in NAEP scores between students who responded, "a little bit like me" and "somewhat like me". However, students who reported being "quite a bit like me" and "exactly like me" scored significantly higher. Students who said this was "quite a bit like me" scored higher than those who indicated "not at all like me", "a little like me", and "somewhat like me". Lastly, students who responded "exactly like me" scored significantly higher than students in all other categories.

Table 13 presents the difference in means results for the response to "I take math because it will help me in the future", 2015. Alpha was set at 0.05. Overall, students who responded "strongly disagree" scored significantly lower than those who chose any other category. There was no significant difference in NAEP scores between students who responded "agree" and "disagree". Students who responded "strongly agree" scored significantly higher than students in all other categories. 
Table 12. The difference in Average Scale Scores Between Variables for Math for Future Benefit: 2019

\begin{tabular}{|c|c|c|c|c|}
\hline & 1 & 2 & 3 & 4 \\
\hline \multicolumn{5}{|l|}{ 1. Not at all like me } \\
\hline \multirow[t]{4}{*}{ 2. A little bit like me } & $>$ & & & \\
\hline & Diff $=12$ & & & \\
\hline & $\mathrm{P}$-value $=0.0000$ & & & \\
\hline & Family size $=10$ & & & \\
\hline \multirow[t]{4}{*}{ 3. Somewhat like me } & $>$ & $X$ & & \\
\hline & Diff $=11$ & Diff $=-1$ & & \\
\hline & $\mathrm{P}$-value $=0.0000$ & $\mathrm{P}$-value $=0.5442$ & & \\
\hline & Family size $=10$ & Family size $=10$ & & \\
\hline \multirow[t]{4}{*}{ 4. Quite a bit like me } & $>$ & $>$ & $>$ & \\
\hline & Diff $=22$ & Diff $=10$ & $\operatorname{Diff}=11$ & \\
\hline & $\mathrm{P}$-value $=0.0000$ & $\mathrm{P}$-value $=0.0000$ & $\mathrm{P}$-value $=0.0000$ & \\
\hline & Family size $=10$ & Family size $=10$ & Family size $=10$ & \\
\hline \multirow[t]{4}{*}{ 5. Exactly like me } & $>$ & $>$ & $>$ & $>$ \\
\hline & Diff $=27$ & Diff $=15$ & $\operatorname{Diff}=16$ & Diff $=4$ \\
\hline & $\mathrm{P}$-value $=0.0000$ & $\mathrm{P}$-value $=0.0000$ & $\mathrm{P}$-value $=0.0000$ & $\mathrm{P}$-value $=0.0010$ \\
\hline & Family size $=10$ & Family size $=10$ & Family size $=10$ & Family size $=10$ \\
\hline \multicolumn{5}{|l|}{ LEGEND: } \\
\hline$<$ & Significantly lower. & & & \\
\hline$>$ & Significantly higher. & & & \\
\hline$X$ & $\begin{array}{l}\text { No significant } \\
\text { difference. }\end{array}$ & & & \\
\hline
\end{tabular}

Table 14 presents the difference in means results for the response to "I take math because it will help me in the future", 2013. Alpha was set at 0.05. Overall, students who responded "strongly disagree" scored significantly lower than those who chose any other category. Students who reported "agree" scored higher than those who said, "disagree". Students who responded "strongly agree" scored significantly higher than students in all other categories

This study was designed to evaluate if a gap existed between the mathematics scores of 12thgrade public school students who have different levels of interest in higher education. Through a quantitative study utilizing the 12th-grade NAEP mathematics data from 2013, 2015, and 2019, it was determined that interest in higher education does play a role in a student's NAEP scores. This relationship appears to persist over time. The following sections will discuss how findings from the NAEP Data Explorer provide insight into this study's research questions. 
Table 13. The difference in Average Scale Scores Between Variables for Math for Future Benefit: 2015

\begin{tabular}{llll}
\hline & 1 & 2 & 3 \\
\hline $\begin{array}{l}\text { 1. Strongly disagree } \\
\text { 2. Disagree }\end{array}$ & $>$ & & \\
& Diff $=10$ & & \\
& P-value $=0.0000$ & & \\
& Family size $=6$ & & \\
3. Agree & $>$ & X & \\
& Diff $=12$ & Diff $=2$ & \\
& P-value $=0.0000$ & P-value $=0.1092$ & \\
4. Strongly agree & Family size $=6$ & Family size $=6$ & $>$ \\
& $>$ & $>$ & Diff $=15$ \\
& Diff $=27$ & Diff $=17$ & P-value $=0.0000$ \\
LEGEND: & P-value $=0.0000$ & P-value $=0.0000$ & \\
$<$ & Family size $=6$ & Family size $=6$ & Family size $=6$ \\
$>$ & Significantly lower. & & \\
$X$ & Significantly higher. & & \\
\hline
\end{tabular}

Table 14. The difference in Average Scale Scores Between Variables for Math for Future Benefit: 2013

\begin{tabular}{llll}
\hline & 1 & 2 & 3 \\
\hline 1. Strongly disagree & & & \\
2. Disagree & $>$ & & \\
& Diff $=8$ & & \\
& P-value $=0.0000$ & & \\
3. Agree & Family size $=6$ & & \\
& $>$ & Diff $=2$ & \\
& Diff $=11$ & P-value $=0.0159$ & \\
& P-value $=0.0000$ & Family size $=6$ & \\
4. Strongly agree & Family size $=6$ & $>$ & Diff $=14$ \\
& $>$ & Diff $=16$ & P-value $=0.0000$ \\
& Diff $=24$ & P-value $=0.0000$ & \\
LEGEND: & P-value $=0.0000$ & Family size $=6$ & Family size $=6$ \\
$<$ & Family size $=6$ & & \\
$>$ & Significantly lower. & \\
$X$ & Significantly higher. & \\
\hline
\end{tabular}




\subsection{Research Question 1: College Entrance Exams}

In answering research question one, How does taking college entrance exams to relate to 12th-grade NAEP mathematics scores?, the average scale scores and standard deviations of students who completed college entrance (SAT/ACT) were compared to those who did not complete these exams. Overall three sampled years, students who completed college entrance exams scored significantly higher on the mathematics NAEP. However, this interaction only has an average Cohen's $d$ of .32 across this timeframe, indicating that while standardized tests may explain some of the variances in scores, they may not be the most significant factor.

In line with previous research from Scott, Ingles, and Owings (2007), college entrance exams are still correlated with success in mathematics NAEP. But the strength of this effect varies between the tests. The strength of the effect was higher in $2013(d=.42)$ and $2015(d=.41)$, than in $2019(d$ $=.14)$. This difference in effect size might exist because universities are moving toward testoptional and test flexible policies. To improve equity and fairness in the admissions process, many schools no longer require that all applicants submit entrance exam scores with their applications (Jaschik, 2019). As more schools move to test-optional and as the COVID-19 pandemic makes the delivery of standardized tests challenging, we can anticipate the effect size will continue to decrease.

\subsection{Research Question 2: Financial Aid Application Completion}

In answering research question two, How does completing the FAFSA relate to 12 th-grade NAEP mathematics scores?, the average scale scores and standard deviations of students who completed the FAFSA were compared to those who did not. Overall three sampled years, students who completed the FAFSA scored significantly higher on the mathematics NAEP. The effect size remained consistent across this timeframe, with a small-to-moderate effect. The findings from this study are consistent with Feeny and Heroff (2013), which found that students with higher academic performance in high school were more likely to complete the FAFSA.

Further, the stability of this effect illustrates that higher NAEP mathematics scores are a predictor of FAFSA completion. It is essential to understand factors that influence FAFSA completion, as the FAFSA is tied to financial literacy, higher education enrollment, and persistence in higher education programs. Administrators at both the high school and higher education level have a stake in understanding which students decide to complete the FAFSA and how they perceive financial aid concerning their overall future education. If early educational interventions can improve students' mathematics comprehension, this knowledge may lead to better financial literacy.

\subsection{Research Question 3: The Role of College Applications}

In answering research question three, How does applying to college relate to 12 th-grade NAEP mathematics scores? the average scale scores and standard deviations of students who applied to two-year and four-year institutions were compared to those who did not apply to those 
types of institutions. Overall three sampled years, students who applied to four-year colleges scored significantly higher on the mathematics NAEP than those who did not apply to four-year institutions. Interestingly, students who applied to two-year colleges scored significantly lower on the mathematics NAEP than those who did not apply to two-year colleges. The results from this study suggest that there is a connection between academic performance in mathematics and the type of higher education a student pursues.

Previous research shows that academic performance in high school is a factor in a student's decision to pursue higher education. Joshi and Beck (2009) illustrate that a student's academic aptitude will influence their decision to choose a two- or four-year college. Students who perform better academically tended to favour four-year institutions. Students with GPAs between 1.75 and 2.75 were the most likely to choose two-year colleges (Stokes \& Somers, 2009). These findings are supported in this data analysis. Students who sought two-year institutions had significantly lower NAEP mathematics scores.

Of the factors in this study, applying to a four-year institution had the largest effect on NAEP mathematics scores $(2019, d=.90 ; 2015, d=.93 ; 2013, d=.96)$. Even though the strength of the effect decreases over time, the value of this effect illustrates the importance of motivating students toward applying to four-year colleges early in their educational career. The college counselling services offered by a high school can play an important role in college application rates (Bryan, Moore-Thomas, Day-Vines, \& Holcomb-McCoy, \& 2010). Interventions designed to help students find a path to four-year programs, like these counselling services, could help students understand how to apply to four-year institutions and help them feel more confident to do so.

\subsection{Research Question 4: Students Perceived Benefit of Mathematics}

Research question four discussed how students' perceived benefit of mathematics impacts their 12th-grade NAEP mathematics scores. The average scale scores and standard deviations of the following two NAEP questions were explored: I take math to meet my high school graduation requirements, and I take math because it will help me in the future. These results indicate that student interest in mathematics plays a more precise role in interpreting NAEP scores than whether a student took a math course for graduation. On balance, students who indicated that they took math because it will help them score better than peers in all other categories. However, the results of taking math to meet graduation requirements were more mixed. This may be because of curricular requirements, where even though students are interested in math, they are also required to take math courses. The effect sizes further illustrate this within these questions. The largest effect size for $I$ take math to meet my high school graduation requirements ranged from $d=.26$ (2019) to $d=.56$ (2015/2013). The largest effect size from taking math because it will help me in the future ranged from $d=.77$ (2013) to $d=.81$ (2015). 
These findings suggest the importance of highlighting the applications of mathematics in everyday life. This is consistent with Mangu, Lee, Middleton, and Nelson (2015), who found that students are more willing to expend effort toward a subject when they perceive future utility from it. It is important that learners can see how the content they learn in the classroom can be applied to their interests and future. Instructors and institutions should prioritize such programs and give students opportunities to explore their identity with mathematics.

\section{Conclusion}

The purpose of this study was to explore if a gap exists between the mathematics scores of 12th-grade public school students who have different levels of interest in higher education. This was accomplished by analysing NAEP data, focusing on questions related to interest in higher education and the perceived future benefit of mathematics. Overall, the study found that students who are taking steps toward higher education, specifically toward four-year institutions, have higher NAEP mathematics scores. Students who completed college entrance exams (SAT/ACT) performed statistically better on the 12th-grade mathematics NAEP than those who did not. Students who completed the FAFSA performed statistically better on the 12th-grade mathematics NAEP than those who did not. Students who applied to four-year colleges performed statistically better on the 12th-grade mathematics NAEP than those who did not. However, students who applied to two-year colleges performed statistically lower than those who did not apply to two-year colleges. Perceiving a future benefit to mathematics had a significant influence on mathematics scores. This paper will now explore three implications tied to this research.

\section{References}

Alon, S. (2011). Who benefits most from financial aid? The heterogeneous effect of need-based grants on students' college persistence. Social Science Quarterly, 92(3), 807-829.

Avery, C., \& Kane, T. J. (2004). Student perceptions of college opportunities: The Boston COACH program. In C. Hoxby (Ed.), College choices: The economics of where to go, when to go, and how to pay for it (pp. 355-394). University of Chicago Press.

Becker, L. (March 20, 2000). Effect size calculators: effect size. University of Colorado. https://lbecker.uccs.edu/effect-size.

Bettinger, E. P., \& Evans, B. J. (2019). College guidance for all: A randomized experiment in precollege advising. Journal of Policy Analysis and Management, 38(3), 579-599.

Bettinger, E. P., Long, B. T., Oreopoulos, P., \& Sanbonmatsu, L. (2012). The role of application assistance and information in college decisions: Results from the H\&R Block FAFSA experiment. The Quarterly Journal of Economics, 127(3), 1205-1242.

Bohrnstedt, G.W., Zhang, J., Park, B. J., Ikoma, S., Broer, M., \& Ogut, B. (2020). Mathematics Identity, self-efficacy, and interest and their relationships to mathematics achievement: A longitudinal analysis. In: Serpe R., Stryker R., \& Powell B. (eds), Identity and Symbolic Interaction. Springer, Cham. https://doi.org/10.1007/978-3-030-41231-9_7. 
Bond, J., \& Zhang, M. (2017). The impact of conversations on fourth grade reading performance What NAEP data explorer tells? European Journal of Educational Research, 6(4), 407-417. doi: 10.12973/eu-jer.6.4.407.

Bruce, M., \& Bridgeland, J. (2014). The mentoring effect: Young people's perspectives on the outcomes and availability of mentoring. A Report for Mentor: The National Mentoring Partnership. Civic Enterprises.

Retrieved from: https://files.eric.ed.gov/fulltext/ED558065.pdf.

Bryan, J., Moore-Thomas, C., Day-Vines, N., \& Holcomb-McCoy, C. (2010). School counselors as social capital: The effects of high school college counseling on college application rates. Journal of Counseling \& Development, 89, 190-199.

Bureau of Labor Statistics (2020). College enrollment and work activity of recent high school and college graduates: 2019. News release: U.S. Department of Labor. Retrieved from: https://www.bls.gov/news.release/pdf/hsgec.pdf.

Carpena, F., Cole, S. A., Shapiro, J., \& Zia, B. (2011). Unpacking the causal chain of financial literacy. World Bank Policy Research Working Paper No. 5798. Retrieved from: https://ssrn.com/abstract=1930818.

Cohen, J. (1988). Statistical power analysis for the behavioral sciences (2nd ed.). Hillsdale, NJ:Lawrence Earlbaum Associates.

Erickson, L. D., McDonald, S., \& Elder Jr, G. H. (2009). Informal mentors and education: Complementary or compensatory resources?. Sociology of education, 82(4), 344-367.

Feeny, M., \& Heroff, J. (2013). Barriers to need-based financial aid: Predictors of timely FAFSA completion among low-income students. Journal of Student Financial Aid, 43(2), 65-85.

Hannula M.S., Di Martino, P., Pantziara, M., Zhang, Q., Morselli, F., Heyd-Metzuyanim, E., et al. (2016). Attitudes, beliefs, motivation, and identity in mathematics education. Springer Nature. https://doi-org.cmich.idm.oclc.org/10.1007/978-3-319-32811-9_1.

Jaschik, S. (2019, April 1). New push for test options. Inside Higher Ed. Retrieved from: https://www.insidehighered.com/admissions/article/2019/04/01/more-colleges-gotest-optional-admissions.

Joshi, P., Beck, K., \& Nsiah, C. (2009). Student characteristics affecting the decision to enroll in a community college: Economic rationale and empirical evidence. Community College Journal of Research and Practice, 33(10), 805-822.

Kafka, A. (2019, December 2). Why more colleges are teaching financial wellness. Retrieved from: https://www.chronicle.com/article/Why-More-Colleges-Are-Teaching/247640.

LaDell-Thomas, J. \& Zhang, M. (2017). Computer use and reading achievement: Evidence from the 2015 NAEP fourth grade reading scores. International Journal of Current Research, 9(11), 814-826.

Lopez, F. \& Lent, R. (1992). Sources of mathematics self-efficacy in highschool students. The Career Development Quarterly, 41, 3-12. 
Mangu, D., Lee, A., Middleton, J. A., \& Nelson, J. K. (2015). Motivational Factors Predicting STEM and Engineering Career Intentions for High School Students. 2015 IEEE frontiers in education conference proceedings (pp. 2285-2291). IEEE: El Paso, TX.

McKinney, L., \& Novak, H. (2012). The relationship between FAFSA filing and persistence among first-year community college students. Community College Review, 41(1), 63-85.

McKinney, L., \& Novak, H. (2015). FAFSA filing among first-year college students: Who files on time, who doesn't, and why does it matter?. Research in Higher Education, 56(1), 1-28.

Morgan, T. L., Zakem, D., \& Cooper, W. L. (2018). From high school access to postsecondary success: An exploratory study of the impact of high-rigor coursework. Education Sciences, 8(191), 1-20. https://doi.org/10.3390/educsci8040191.

National Center for Educational Statistics. (2020a). What does the NAEP Mathematics assessment measure? https://nces.ed.gov/nationsreportcard/mathematics/whatmeasure.aspx.

National Center for Educational Statistics. (2020b). Select the participants. https://nces.ed.gov/nationsreportcard/assessment_process/selection.aspx.

National Center for Educational Statistics. (2020c). Frequently asked questions. https://nces.ed.gov/nationsreportcard/about/faqs.aspx\#: :text=For\%20assessments $\% 20$ to $\% 2$ 0report\%20national,schools\%20in\%20each\%20participating\%20jurisdiction.

National Center for Educational Statistics. (2018a). An overview of the NAEP. https://nces.ed.gov/nationsreportcard/subject/about/pdf/naep_overview_brochure_2018.pdf

National Center for Educational Statistics. (2018b). Select the participants. Retrieved from https://nces.ed.gov/nationsreportcard/assessment_process/selection.aspx.

National Center for Educational Statistics. (2017). Grade 12 participation and engagement in NAEP. Department of Education. Retrieved from: https://www.nationsreportcard.gov/focus_on_naep/files/g12_companion.pdf.

National Center for Educational Statistics. (2008). NAEP technical documentation: NAEP data explorer.https://nces.ed.gov/nationsreportcard/tdw/database/data_tool.asp\#: :text=The $\% 20$ NAEP\%20Data\%20Explorer\%20is,.gov\%2Fnationsreportcard\%2Fnde.

National Collegiate Attainment Network. (2021, February 16). National FAFSA completion rates for high school seniors and graduates. National Collegiate Attainment Network. Retrieved from:https://www.ncan.org/page/NationalFAFSACompletionRatesforHighSchoolSeniorsan dGraduates\#: :text=Using\%20the\%20most\%20recent\%20data,school\%20graduates $\% 20$ is\% $2061 \% 20$ percent.

Novak, H., \& McKinney, L. (2011). The consequences of leaving money on the table: Examining persistence among students who do not file a FAFSA. Journal of Student Financial Aid, $41(3), 5-23$.

Owen, L., \& Westlund, E. (2016). Increasing college opportunity: school counselors and fafsa completion. Journal of College Access, 2(1), 3.

Schneider, B., Broda, M., Judy, J., \& Burkander, K. (2013). Pathways to college and STEM careers: Enhancing the high school experience. New directions for youth development, 2013(140), 929. 
Schneider, M., Kitmitto, S., Muhisani, H., \& Zhu, B. (2015). Using the National Assessment of Educational Progress as an indicator for college and career preparedness. American Institute for Research. Retrieved from: https://www.air.org/sites/default/files/downloads/report/Using-NAEP-as-an-IndicatorCollege-Career-Preparedness-Oct-2015.pdf.

Scott, L. A., Ingels, S. J., \& Owings, J. A. (2007). Interpreting 12-graders; NAEP-scaled mathematics performance using high school predictors and postsecondary outcomes from the National Education Longitudinal Study of 1988 (NELS:88): Statistical analysis report. National Center for Education Statistics, Institute of Education Sciences. Retrieved from: https://nces.ed.gov/pubs2007/2007328.pdf.

Smith-Barrow, D. (2018, July 20). Are too few college students asking for federal aid. The Hechinger Report. Retrieved from: https://hechingerreport.org/are-too-few-college-studentsasking-for-zederal-aid/.

Stokes, T. \& Somers, P. (2009). Who enrolls in two-year colleges? A national study of price response. Journal of Student Financial Aid, 39(1), 4-18.

Walton, G. M., \& Cohen, G. L. (2007). A question of belonging: race, social fit, and achievement. Journal of personality and social psychology, 92(1), 82-96.

Zhang, M. \& Li, X. (2009). Exploring the relationship between non-school factors and NAEP reading scores. STETS Language and Communication Review, 8(1), 1-8. 